\title{
Web-based mind mapping learning media to imporve understanding of economic policy materials
}

\author{
Meylinda Lukito Sari *, Muhammad Abdul Ghofur \\ Economic Education Study Program, Universitas Negeri Surabaya. \\ J1. Rektorat Unesa, Lidah Wetan, Lakarsantri, Surabaya, Jawa Timur 60213, Indonesia. \\ meylindalukitosari@gmail.com \\ * Corresponding Author
}

\section{ARTICLE INFO}

\section{Article History}

Received:

30 May 2020;

Revised:

1 June 2020;

Accepted:

10 August 2020

\section{Keywords}

Mind mapping;

Learning media;

Student's

understanding;

Economics

\begin{abstract}
Against a background of students' lack of understanding of monetary and fiscal policy, the research conducted aims to develop learning media that is expected to be able to overcome these problems. Learning media developed using a mind mapping and web-based approach. This type of research used in this study is Research and Development with the 4D development model (Define, Design, Develop, \& Disseminate). Product trials conducted limited to 20 students by analyzing the results of the pre-test and post-test, which were calculated using the gain score and t-test. The test results show that webbased mind mapping learning media can improve students' understanding. Because by using this learning media, the active mental processes of each student become aroused, the material provided so that it is easy to remember. However, this web-based mind mapping learning media is still being tested on a limited basis, so it needs to be trialed in the broader audience to get more productive advice.
\end{abstract}

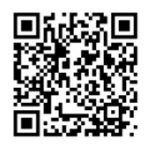

This is an open access article under the $\mathrm{CC}-\mathrm{BY}-\mathrm{SA}$ license.

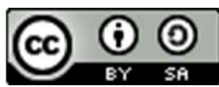

\section{INTRODUCTION}

Appropriate technology implementation can directly affect student achievement in the learning process. Educational technology is both an analysis and practice to support the learning process. Technology can improve performance by forming, utilizing, and managing technology's operations and sources accordingly (Richey, 2008). The application of learning technology currently includes the use of information and communication technology processes and products to overcome the problems of education and learning, and this effort has many benefits and advantages (Surjono, 2010). Technological innovation radically changes the way people interact, teaching methods are no exception, changing the way education and training programs are provided (Sinclair, Kable, LevettJones, \& Booth, 2016). Along with the development of Information Technology Systems, the world of education is continuously moving forward actively, especially in building various learning media that are expected to be able to spread a positive impact on students. The media used in learning with the help of Information and Technology can utilize to make learning activities more enjoyable and spread positive impacts on academic performance in the form of student learning outcomes (Chuang, 2014).

The expansion of web-based learning is also supported by the technical evolution of mobile devices, giving life to the concept of mobile learning, which meets the demands of today, namely a society that continues to grow and be flexible (Clay, 2011). The most widely cited technical advantages of web-based learning include universal accessibility, the availability of regularly 
updated content, and the possibility to connect with other topics (Daiute, 2013). Surjono (2013) argues that web-based learning media or commonly called e-learning are now increasingly popular because of their flexibility and effectiveness by presenting learning materials using the internet that can run anytime and anywhere. So the use of web-based learning media can be used many times as desired to increase student understanding. For this reason, media development is needed in the learning process that is suitable and able to meet the interests of students. In making learning media, there needs to be an element of creativity and innovation that is expected to help students in making it easier to understand the learning material presented by the teacher. Learning media is a tool that students can use to recognize and understand things easily (Rusman, 2013).

The learning of high school students in Indonesia, in general, is still merely gathering the knowledge conveyed by the teacher to students. This kind of learning is still far from the meaning of learning for life. In general, learning in schools based on learning in the classroom, which prioritizes learning from books and teachers, causes learning to be less dynamic, learning that is not directed by oneself (Prabowo, 2010). This kind of learning, in addition to less stimulating the growth of students' critical thinking, will also consume more learning time in class. The time that should be maximized for deeper learning becomes a less essential portion of knowledge. Most student learning in high school goes like this, and there have been no significant changes from year to year, including in SMA 1 Gedangan. In general, the learning activities of economic subjects in SMA 1 Gedangan still rely on face-to-face learning in the classroom with an allocation of 2 hours of study time each time faceto-face. This time allocation felt to be less effective so that students' understanding is not optimal. This matter indicated by only 9 of the 36 students whose grades reached the minimum learning completeness limit, or as many as $75 \%$ of students did not reach the minimum limit.

Based on these facts, the researcher tries to develop learning media that can be accessed inside and outside of teaching and learning activities in the classroom that are used as support in the learning process so that students can understand the material that has been delivered by educators. Following the cognitive theory, which explains that learning activities are organizing cognitive aspects as well as responses to produce understanding (Harmi, 2010). For this reason, economic subjects are suitable for use in developing mind mapping because the material presented is more concise and clear so that students are expected to experience an increase in understanding. Buzan (2013) revealed that the brain naturally prefers keywords that represent the big picture, and wordy sentences are the best way to save or remember verbal images and ideas. For that, we need a breakthrough that can provide solutions for students to master the material, namely, by using mind mapping. Mind Mapping illustrates one of the cooperative teaching frameworks that considered suitable for increasing student concentration and memory because mind mapping is mapping thoughts that contain the keywords of a topic (Rahayu, Santosa, \& Endarto, 2015). Mind mapping is a learning method that is considered better for supporting the way of thinking of the brain coherently because it utilizes a graphical approach obtained from the human mind. That has the benefit of presenting concepts, in general, to be able to unlock the potential contents of the brain (Prayudi, 2008). Mind Mapping is useful to facilitate students' memory of a series of concepts (D'Antoni, 2009). Information and understanding created from Mind Mapping can stay longer in long term memory, this is because the brain of a person is more comfortable to remember the shape of symbols, sounds, feelings, and images (Shoimin, 2014).

Aulia (2014) revealed that among the benefits of mind mapping are: as a whole, it is easy to see a picture of the content of matter, makes it easier for the brain to manage, match, remember and form relationships, makes it easy to add new information, faster in reviewing, and thought maps are unique. The use of mind mapping is possible to support students, even with various backgrounds, interpreting their understanding of knowledge (Evrekli, Inel, \& Balim, 2011). Research conducted by Sim and Pop (2012) obtained the results that with mind mapping, students not only took an active part in the teaching and learning process, but they also saw the results of their efforts and learning. Another study conducted by Darusman (2014) found that learning using mind mapping had better levels of thinking ability achievement. Specifically, in the study of monetary and fiscal policy, Biktimirov and Nilson (2006) recommend using mind mapping. The use of mind mapping will significantly assist students in learning about economics, especially at the introductory level. Compared with text, visual displays in mind mapping are far more effective at conveying knowledge 
to students with various learning styles. However, it will be more effective if it is delivered interactively to avoid relational ambiguity. This problem often arises because of the different visual appearance of the cross-modal components (Yu, Zhang, Yang, Qin, \& Hu, 2020). Mind mapping is also beneficial in facilitating students in cognitive processes and the retention of monetary and fiscal policy material. By using graphs as a learning aid for monetary and fiscal policy, students can avoid the difficulties of complicated and tedious understanding. The time used by the teacher will also be shorter because mind mapping will help students construct the material, and students themselves have done several stages of learning.

Cheng, Wang, and Mercer (2014) also conducted research that found that the concept of mind mapping enriched the representation of knowledge and communication, making it easier for students to clarify and explain their ideas. Furthermore, Fu, Lin, Hwang, and Zhang's research (2019) found that mind mapping can make students easily record their thoughts. Benefits students to more easily remember, evoke, and relate their past travel experiences, and finally to develop a big picture of learning material. Also, Otaduy and Diaz (2017) researched with the result that mind mapping facilitates students' understanding of using technology. Although mind mapping does not depend on modern technology, web-based technology with image and video components makes students more adaptable than text alone (Biktimirov \& Nilson, 2006). Although digital technology is not always beneficial for every child, it is still important to consider. Research by Bergdahl, Nouri, Fors, and Knutsson (2020) proves that digital learning media can improve the learning performance of highachieving students. They stated they could concentrate more when knowing to use digital technology. On the other hand, in low-achieving students, digital technology is used to escape when learning is boring.

Based on these results, the researchers developed a web-based mind mapping learning media on economic subjects, which aims as a learning medium to help improve student understanding. This media is expected to use in supporting the teaching and learning process that is carried out through face to face and distance. In this development, researchers measured the success of the media with practicality indicators that analyzed the results of students 'responses to the media developed and the effectiveness obtained from increasing students' understanding.

\section{METHOD}

This type of research is included in the Research and Development category. Sugiyono (2016) revealed that Research and Development research is a research method used to create a particular product after it tests the product's success. The model is used in the development of a 4-D model. Thiagarajan's 4-D development model has four stages: Define, Design, Development, Disseminate (Trianto, 2014). The defining stage is used to determine and define the learning process requirements and gather various information related to the product to develop. After obtaining information about the problem from the defining stage, the design stage is then carried out. The design phase is carried out to design features that are useful in learning activities. The development phase aims to build media based on a predetermined design, then revised and validated based on expert input. After testing the media that has developed in a limited manner, and experts have revised the instrument, the next step is dissemination. The dissemination phase aims to disseminate the products that have developed. This study only reached the development stage and limited distribution for the benefit of this research on an online page.

In this study, researchers used a limited trial using the One Group Pretest-Postest Design. According to Sugiyono (2016), One Group Pretest-Postest Design is a product trial technique by giving pre-test before treatment and after treatment given a post-test to see changes in student learning outcomes between before and after treatment. This method is used to get a limited picture of the results of media development. It did not rule out the possibility for researchers and anyone to use this product in further research with broader subjects. The test subjects in this media's development were students of class XI IPS in SMA Negeri 1 Gedangan. This trial will be conducted on 20 students using monetary and fiscal policy material. According to Sadiman, Rahardjo, Haryono, \& Harjito (2007) revealed that a media feasibility test could be conducted on 10-20 students to represent the target.

Volume 7, No. 2, September 2020 
The assessment tools used in this study used a closed questionnaire and an open questionnaire. The open and closed questionnaire contents include suggestions and assessment scores that must be filled out by experts. The open questionnaire is a questionnaire where respondents can provide content or opinions according to circumstances. The closed questionnaire is a questionnaire outlined in a closed-form so that respondents can answer by choosing the answer that feels most appropriate (Riduwan, 2016). The open questionnaire includes 1.) Material expert review sheet, a worksheet filled out by experts who are lecturers and educators. The study sheet was used to obtain input and revisions related to learning media adjusted for core competencies and basic competencies; 2.) A media expert review sheet, a sheet filled by media experts to obtain advice as well as input related to learning media; and 3.) Evaluation expert review sheet, that is, the evaluation sheet given will be filled in by the evaluation expert to obtain advice and input related to the evaluation of items.

Meanwhile, closed questionnaires include 1.) Material expert validation sheet, which is a sheet filled out by two material experts after trying out the developed learning media. This validation sheet conducted to determine the level of eligibility of the material on the learning media created; 2.) The media expert validation sheet is the sheet filled out by the media expert after reviewing the researcher's learning media. This validation sheet used to determine the feasibility of learning media; 3.) The evaluation expert validation sheet is a sheet filled out by the evaluation expert after seeing the pre-test questions. This validation sheet was used to determine the feasibility of the evaluation problem; and 4.) Questionnaire responses of students is a questionnaire used to see students' responses from the learning media used during the trial. The eligibility criteria are presented in Table 1.

Table 1. Validation Criteria

\begin{tabular}{cc}
\hline Rating & Scale \\
\hline $0 \%-20 \%$ & Very Ineligible \\
$21 \%-41 \%$ & Not Eligible \\
$41 \%-60 \%$ & Are Decent Enough \\
$61 \%-80 \%$ & Eligible \\
$81 \%-100 \%$ & Very Worthy \\
\hline
\end{tabular}

Source: (Riduwan, 2016)

Analysis of the validity and reliability of the items used. This analysis to see the validity and reliability of the evaluation questions. Validity used as a measure to prove the validity and validity of the instrument (Arikunto, 2007). The instrument can say valid when it can measure what you want and provide data from variables precisely. The validity of item evaluation is processed using the biserial point correlation formula (Arikunto, 2007). Meanwhile, Ghozali (2009) argues that reliability represents a tool used to measure a questionnaire that includes indicators of variables or constructs. A questionnaire/test is relatively reliable or reliable when the answers obtained from the statement classified as consistent or stable from time to time. The item validity testing technique uses the Spearman Rank correlation coefficient between each item's scores and the total score of the indicators. The reliability of the item items tested using the internal consistency method (Karras, 1997). For the internal consistency method, the best-known technique is the Cronbach Alpha technique.

Meanwhile, Ghozali (2009) argues that reliability represents a tool used to measure a questionnaire that includes indicators of variables or constructs. A questionnaire/test is relatively reliable or reliable when the answers obtained from the statements are classified as consistent or stable from time to time. It recommended that a reliability coefficient between $0.70-0.80$ is considered good enough for primary research purposes (Kaplan \& Saccuzzo, 2001). The next step is data analysis, an activity carried out after all data has been collected. This research uses descriptive analysis techniques and inductive (correlational) statistics. Descriptive statistics are used in the analysis phase. This stage is carried out to determine the characteristics of student learning outcomes. Descriptions also made to make it easier to see the results of evaluations from experts. Inductive statistics are used to test the significance of increasing student learning outcomes after using the 
developed learning media. Measurement of this learning improvement using the test instrument conducted before and after learning using learning media. Test results were analyzed using gain score analysis. Data normality test was performed to determine the use of the t-test or Wilcoxon.

The test instrument used first performed an analysis of the level of difficulty, different power, and distractor function. The level of difficulty of item items, according to Sukardi (2011), is a number that shows the proportion of students who answered correctly in one problem conducted using an objective test. According to Daryanto (2010), the right questions are questions that are not too easy or not too difficult. Daryanto (2010) explains that the power of distinguishing questions is the ability of something to differentiate between high-ability students and low-ability students. Knowing the distinguishing features of items is very important because it is one of the basic guidelines in compiling items of learning outcomes test items (Sudijono, 2009).

Every choice of the answer was also noted for the deception. According to Thoha (2001), the purpose of using a distractor is to outwit those who are less capable so that it can be distinguished from the able. Arikunto (2012) explains that a distractor can be said to function well if the distractor has excellent appeal for test-takers who lack understanding of the concept or lack of mastering the material. Distractors are declared to be able to carry out their functions correctly if the distractor has chosen by at least $5 \%$ of all test takers.

\section{FINDINGS AND DISCCUSIONS}

Learning media used to help teaching and learning activities. Development of learning media carried out following the applicable curriculum. At this time, the school was applying the revised edition 2013 curriculum in 2017. This curriculum emphasizes four aspects of assessment, namely the assessment of aspects of knowledge, skills, attitudes, and behavior. The expected benefit is that students become more active, creative, and innovative through a scientific approach when students are confronted with various problems seen from a scientific approach. They often have difficulty understanding what is intended, so they need to study hard.

In the implementation of learning conducted in SMA Negeri 1 Gedangan, students tend to be less active, have difficulty connecting with a problem, and then memorize it. In this case, the material monetary policy and fiscal policy is content that is quite important and heavy for students. The content is related to understanding concepts and memorizing many terms, making it difficult for students to determine and distinguish each concept and term in the material. Students seem less likely to prepare themselves for learning activities. This matter can be seen when the economics teacher enters the room to carry out learning. Many students are still cool with their businesses. For example, some are still playing games in their gadgets, textbooks have not been prepared, and there are still chatting with their classmates. When the teacher reviews the previously studied material, many students have forgotten, thus forcing the teacher to remind or provide a stimulus so that students can remember again.

At this stage of the analysis, students' understanding of each learning indicator is measured. The result found that some signs score lower in understanding compared to other indicators. These indicators include indicators of the purpose and role of monetary policy, monetary policy instruments, and fiscal policy instruments. Most students cannot answer the questions on these indicators. The complete data analysis results can be seen in Table 2 . This indicator will be the main concern in developing the design of web-based mind mapping learning media development. Other indicators are also still considered, but with different proportions, because the level of error of students in answering questions is low.

Indicators that have low scores indicated that many submitters are difficult to understand and memorize. It becomes a significant problem in understanding the material of monetary policy and fiscal policy. This learning media will be created later with more branching mappings on indicators that are less understood. In the indicator that contained, there is also a sub-indicator. In the sub-indicator, a mapping branch will appear again, along with a description of the explanation that appears after completing the empty mapping branch. This explanation made so that students better understand the contents of mapping branching. 
Table 2. Result of Analysis os Student Understanding

\begin{tabular}{|c|c|c|c|c|}
\hline Indicators & Question Item & $\begin{array}{l}\text { The number of students } \\
\text { answered correctly }\end{array}$ & Percentage & $\begin{array}{c}\text { Average } \\
\text { Percentage }\end{array}$ \\
\hline \multirow{2}{*}{ Indicator 1} & Question 6 & 15 & 0.75 & 0.70 \\
\hline & Question 10 & 13 & 0.65 & \\
\hline \multirow[t]{4}{*}{ Indicator 2} & Question 3 & 13 & 0.65 & 0.55 \\
\hline & Question 7 & 10 & 0.50 & \\
\hline & Question 8 & 14 & 0.70 & \\
\hline & Question 20 & 7 & 0.35 & \\
\hline \multirow[t]{7}{*}{ Indicator 3} & Question 1 & 7 & 0.35 & \\
\hline & Question 2 & 13 & 0.65 & 0.49 \\
\hline & Question 4 & 8 & 0.40 & \\
\hline & Question 5 & 8 & 0.40 & \\
\hline & Question 13 & 9 & 0.45 & \\
\hline & Question 15 & 16 & 0.80 & \\
\hline & Question 16 & 8 & 0.40 & \\
\hline Indicator 4 & Question 17 & 14 & 0.70 & 0.70 \\
\hline \multirow[t]{4}{*}{ Indicator 5} & Question 14 & 16 & 0.80 & 0.64 \\
\hline & Question 18 & 15 & 0.75 & \\
\hline & Question 22 & 7 & 0.35 & \\
\hline & Question 24 & 13 & 0.65 & \\
\hline \multirow[t]{7}{*}{ Indicator 6} & Question 9 & 14 & 0.70 & 0.69 \\
\hline & Question 11 & 14 & 0.70 & \\
\hline & Question 12 & 13 & 0.65 & \\
\hline & Question 19 & 14 & 0.70 & \\
\hline & Question 21 & 15 & 0.75 & \\
\hline & Question 23 & 14 & 0.70 & \\
\hline & Question 25 & 13 & 0.65 & \\
\hline
\end{tabular}

This designed media is in the form of mind mapping that can currently be accessed on websites with the page address https://moneterfiskalmls.com or on https://bit.ly/3elXFtH for its offline version that can run on Android. These media have chosen because, with the mind map, the performance of knowledge management can grow. The brain's work system optimally performs, connecting one idea with another so that more ideas and information can be presented. Besides that, it can spur creativity, simplify, and make it easier to remember words. The information presented using mind maps can last for a long time in long term memory. For this reason, researchers develop media that can help students facilitate them in learning material. There are videos, explanations, and mind mapping that are tailored to the learning style and the level of understanding and difficulty of students.

Media development uses a website platform because many students have used various types with various operating systems. Although most of them use Android, not a few are using iOS and Windows. When using a website platform, students can access it using devices with various operating systems and multiple devices. It's just that in using this media, students must be connected to the internet to run it. In this learning media, in addition to being presented with mind mapping material, the presentation is also interactive to provoke the user's active mental processes. Mind mapping charts that can later pair according to the correct answers. Also, there is an explanation of each mind map so that later, students can better understand each material's contents. To deepen the discussion and examples used multimedia. The practice exercises menu is also provided as a means of practice and repetition so that users do not get bored.

This media's initial design was outlined in a sketch using HVS paper with black and red ballpoints as an example of the main menu design in Figure 1, and the material choice menu designs in Figure 2. The use of color themes will later be adjusted to the preferences of students according to the color theme they choose. The voice of students' most choices is to replace the blue color with the theme of sky and clouds. These colors and themes are following the character of students in general. The blue color philosophy represents strength, hope, determination, conscience, confidence, nature, heaven, and intelligence. When viewed from a psychological point of view, blue gives a meaning 
that can be trusted and responsible so that the blue color is considered to have a positive effect on the mind and body-implementation of the main menu design with shades of blue as shown in figure 3.

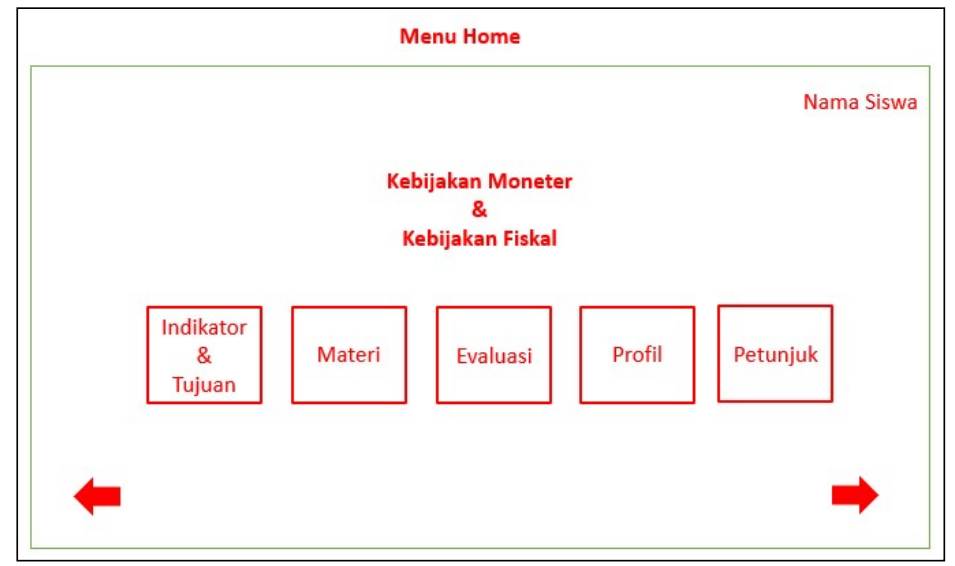

Figure 1. Sketch of the Main Menu

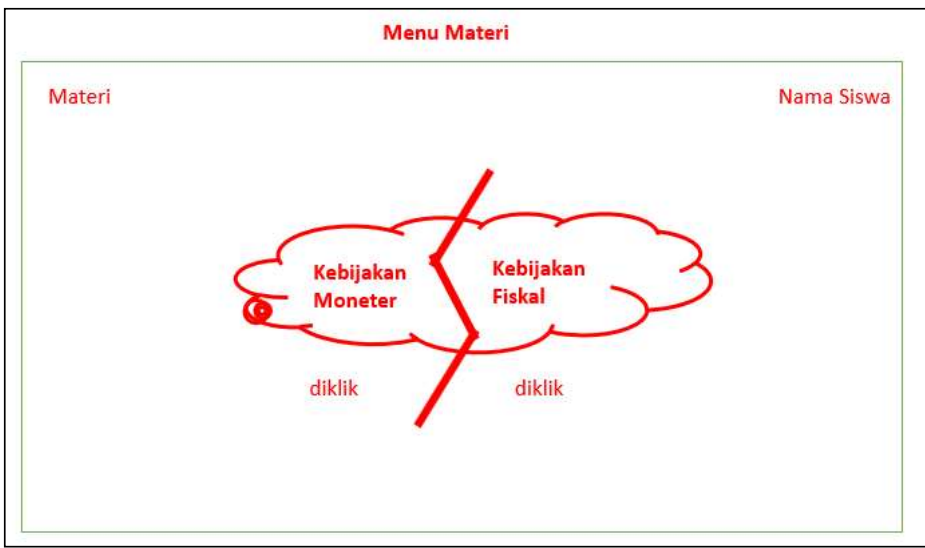

Figure 2. Sketch of the Material Menu

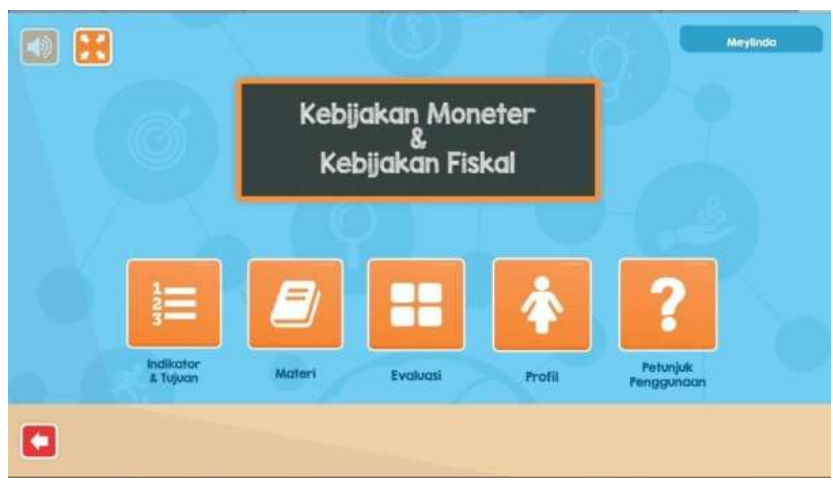

Figure 3. Main Menu

Mind mapping learning media that will develop have features tailored to the needs so that students can use them appropriately. The features are in the form of a front view (home) where later, when students access the mind mapping website, they fill in their data to find out the user's identity. 
Also, there are pages of material that students can use to learn and understand the contents of the material. Students can choose or determine their sub-material in this material page that they do not understand to be studied again. It also provided an evaluation page or questions that can use to review the knowledge and understanding of the material monetary policy and fiscal policy. In this evaluation page, the items provided for students are not the same as other students. So they work on different questions.

The presentation of material designed based on mind mapping made interactive to stimulate students' active mental processes. For example, in monetary policy material in Figure 4. Before students can read the content provided, they asked intuitively to put the branch choices in the right box. After everything is put in place, then they can only read the explanation in each material.

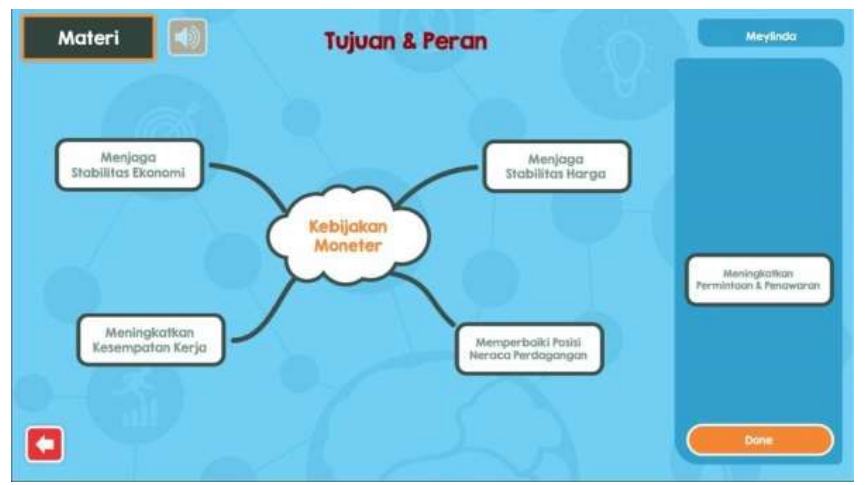

Figure 4. Map of Material

Evaluation features provided to measure the extent to which they have learned. Evaluation pages or practice questions can also be used to review knowledge and understanding of monetary policy and fiscal policy material. In this feature, 50 questions will appear randomly, 15 questions with 5 minutes of processing time. Students with one another will work on different questions. Similarly, if a student repeats the learning session later, he will face a different problem. This matter is intended to reduce the level of the boredom of students in repeating their learning. Examples of displays exercise this problem, as in Figure 5.

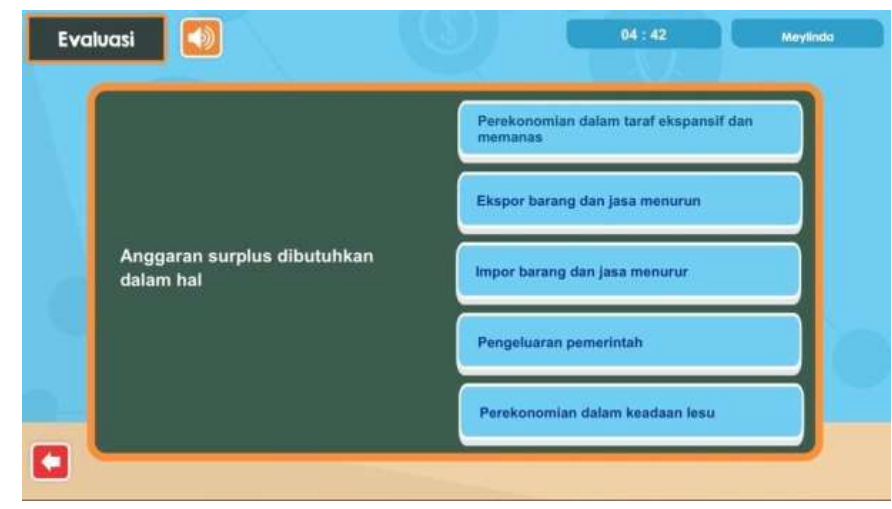

Figure 5. Example Display of Evaluation Features

Limited trials were conducted to measure the ability of this learning media to improve students' understanding of economic policy material. The experiment was conducted on 20 students. The effect of media use was measured through pre-test and post-test. 
Table 3. Item Validity

\begin{tabular}{cccc}
\hline Criteria & Item Number & Amount & Percentages \\
\hline Valid & $3,4,5,8,10,11,12,13,15,16,7,18,19,21,23,24,25,26,27,29,30,31,33,3$ & 25 & $71,4 \%$ \\
Invalid & $4,35$. & 10 & $28,6 \%$ \\
\hline
\end{tabular}

Before the pre-test and post-test instrument, the questions that will use first tested for their validity and reliability. This test aims to make the items used valid and reliable. The tests carried out included indicators of the understanding of monetary policy, the objectives \& role of monetary policy, monetary policy instruments, the understanding of fiscal policy, the purpose \& function of fiscal policy, and fiscal policy instruments. Table 3 informs the results of the validity of the pre-test and post-test items that get the results of the 35 questions that were made. Only 25 questions are declared valid. Next in Table 4. informs the results of the reliability of the items where the value of Cronbach's Alpha is 0.833 . This value is more significant than 0.6 so that the item items used have reliable criteria.

Table 4. Items Reliability

\begin{tabular}{|c|c|}
\hline \multicolumn{2}{|c|}{ Reliability Statistics } \\
\hline Cronbach's Alpha & $\mathrm{N}$ of Items \\
\hline 0.833 & 35 \\
\hline
\end{tabular}

The prototype of learning media that has developed is then reviewed and validated by experts. This validation is carried out by material experts, media experts, and evaluation experts by providing assessments in the form of quantitative scores and input for improvement. Experts carry out this assessment through product validation sheets by giving value with a scale of 1,2,3,4 and 5 with a maximum amount of 5 . This assessment will be used to determine the feasibility of this learning media. Suggestions received are then considered for revision material. Revisions made include improvements to color contrast, writing format, and fonts that are too small. In table 5, the results of the validation of the material obtained a percentage of eligibility of $92.9 \%$, so that in terms of content declared eligible for use learning.

Table 5. Material Expert Validation

\begin{tabular}{lcccc}
\hline \multicolumn{1}{c}{ Validation Aspects } & \multicolumn{2}{c}{ Score } & \multirow{2}{*}{ S Score } & \multirow{2}{*}{ Percentage } \\
& V1 & V2 & & \\
\hline Average of Content Quality and Objectives & 36 & 38 & 74 & $92.5 \%$ \\
Average of Instructional Quality & 19 & 18 & 37 & $92.5 \%$ \\
Average of Technical Quality & 24 & 23 & 47 & $94 \%$ \\
Average of Validation Results & 79 & 79 & 158 & $92.9 \%$ \\
\hline
\end{tabular}

Table 6 informs the results of media validation, which obtained a percentage of overall scores of $88.2 \%$ so that in terms of media, it is appropriate to be used by students. From this information, web-based mind-mapping media can be used as learning media that can help students' learning activities. Furthermore, Table 7 informs that for evaluation validation, the percentage of overall results is $90.9 \%$. Thus the evaluation questions used in the learning media developed are appropriate to be used as an evaluation tool for students' understanding.

This result shows that the mind-mapping based thematic media can accept in either category. Also, Walker and Hess (in Arsyad, 2011) stated that the criteria for media eligibility include completeness of content and objectives, instructional completeness, and technical completeness. Thus, technically and materially, the mind mapping learning media is appropriate to be used by students to support learning activities. 
Table 6. Validation of Learning Media Experts

\begin{tabular}{lcc}
\hline \multicolumn{1}{c}{ Validation Aspects } & Total & Percentage \\
\hline Average of Content Quality and Objectives & Score & \\
Average of Instructional Quality & 22 & $88 \%$ \\
Average of Technical Quality & 20 & $100 \%$ \\
Average of Validation Results & 33 & $82.5 \%$ \\
\hline
\end{tabular}

Table 7. Validation of Evaluation Experts

\begin{tabular}{lcc}
\hline Validation Aspects & Total Score & Percentage \\
\hline Material & 18 & $90 \%$ \\
Construction & 22 & $88 \%$ \\
Language & 10 & $100 \%$ \\
Average of Validation Results & 50 & $90,9 \%$ \\
\hline
\end{tabular}

After completing the review and validation process, a revision of the prototype was then carried out. Learning media that have been revised then tested on students. The trial carried out aimed at obtaining practicality values which were assessed based on students' responses and responses to the web-based mind mapping learning media. Learning outcomes after using this learning media are also analyzed. Product trials in research using the One Group Pretest-Postest Design trial design. In this activity, students asked to fill out a post-test evaluation sheet and response questionnaire. Before the questions used in this trial, the distinguishing power, difficulty level, and distraction effectiveness were analyzed first.

Based on the results of the analysis conducted by researchers on 25 multiple choice questions, it can obtain the results that 11 items that have been done are included in either category. Meanwhile, as many as 14 items were included in the bad category. For the distribution of questions based on the distinguishing power, the group can see in Table 8

Table 8. Classification of item items based on distinguishing features

\begin{tabular}{ccc}
\hline Classification & Question Number & Total \\
\hline Good & 13 & 1 \\
Sufficient & $2,3,4,6,7,9,16,20,21,22$, & 10 \\
Ineffective & $1,5,8,10,11,12,14,15,17,18,19,23,24,25$ & 14 \\
\hline
\end{tabular}

Analysis of the level of difficulty item items obtained 20 items included in the medium category, another five items included in the natural grade. The results of the analysis of the effectiveness of distraction can be said to have been quite useful. This matter can see from the data display in Table 9, which is only a small portion of alternative answers that students did not choose at all. From the product trials that have been conducted, the results of the responses of students get a percentage of $95.9 \%$ so that it can be applied to support the teaching and learning process. This result is also almost the same as the research conducted by Buran and Filyukov (2015). The results of our study found that about $90 \%$ of students have improved their skills in problem-solving. $98 \%$ of respondents prefer to use mind mapping to capture information rather than just reading boring text.

The use of mind mapping techniques was found to be significant in providing different opportunities for students. The research conducted by Kiong, Yunos, Mohammad, Othman, Heong, $\&$ Mohamad (2012) obtained results of more than $89.5 \%$ of the sample giving positive feedback on the aspect of the format, and more than $86.3 \%$ of the sample giving positive feedback on all items for the content aspect of the development mind mapping module. To find out the results of students' level of understanding, they conducted a test analysis of student learning outcomes data using gain score analysis and t-test. 
By calculating the value of the gain score, it is known that an increase in understanding of the material. That is seen from an improvement in student learning outcomes. This conclusion can be seen from the criteria of students' overall average value with a gain score of $>0.3$. The results of calculating the gain score can be seen in Table 10 .

Table 9. Classification of item items based on distinguishing features

\begin{tabular}{crrrrrrl}
\hline Question Nomber & A & \multicolumn{1}{c}{ B } & \multicolumn{1}{c}{ C } & \multicolumn{1}{c}{ D } & \multicolumn{1}{c}{ E } & Answer key & Effectiveness of distraction \\
\hline 1 & $20 \%$ & $20 \%$ & $10 \%$ & $35 \%$ & $10 \%$ & D & Effective \\
2 & $20 \%$ & $5 \%$ & $60 \%$ & $10 \%$ & $0 \%$ & $\mathrm{C}$ & E. Not Effective \\
3 & $65 \%$ & $5 \%$ & $10 \%$ & $10 \%$ & $0 \%$ & $\mathrm{~A}$ & E. Not Effective \\
4 & $30 \%$ & $5 \%$ & $20 \%$ & $10 \%$ & $30 \%$ & $\mathrm{E}$ & Effective \\
5 & $40 \%$ & $15 \%$ & $20 \%$ & $10 \%$ & $10 \%$ & $\mathrm{~A}$ & Effective \\
6 & $15 \%$ & $0 \%$ & $70 \%$ & $5 \%$ & $5 \%$ & $\mathrm{C}$ & B. Not Effective \\
7 & $20 \%$ & $10 \%$ & $45 \%$ & $10 \%$ & $10 \%$ & $\mathrm{C}$ & Effective \\
8 & $10 \%$ & $5 \%$ & $60 \%$ & $5 \%$ & $10 \%$ & $\mathrm{C}$ & Effective \\
9 & $70 \%$ & $5 \%$ & $5 \%$ & $0 \%$ & $10 \%$ & $\mathrm{~A}$ & D. Not Effective \\
10 & $10 \%$ & $60 \%$ & $10 \%$ & $10 \%$ & $5 \%$ & $\mathrm{~B}$ & Effective \\
11 & $5 \%$ & $5 \%$ & $65 \%$ & $5 \%$ & $5 \%$ & $\mathrm{C}$ & Effective \\
12 & $10 \%$ & $15 \%$ & $55 \%$ & $0 \%$ & $10 \%$ & $\mathrm{C}$ & D. Not Effective \\
13 & $45 \%$ & $10 \%$ & $20 \%$ & $10 \%$ & $5 \%$ & $\mathrm{~A}$ & Effective \\
14 & $5 \%$ & $5 \%$ & $70 \%$ & $0 \%$ & $10 \%$ & $\mathrm{C}$ & D. Not Effective \\
15 & $10 \%$ & $75 \%$ & $5 \%$ & $0 \%$ & $0 \%$ & $\mathrm{~B}$ & D. Not Effective \\
16 & $15 \%$ & $5 \%$ & $35 \%$ & $20 \%$ & $10 \%$ & $\mathrm{C}$ & Effective \\
17 & $10 \%$ & $5 \%$ & $65 \%$ & $5 \%$ & $5 \%$ & $\mathrm{C}$ & Effective \\
18 & $20 \%$ & $0 \%$ & $65 \%$ & $5 \%$ & $0 \%$ & $\mathrm{C}$ & B. Not Effective \\
18 & $10 \%$ & $10 \%$ & $65 \%$ & $0 \%$ & $5 \%$ & $\mathrm{C}$ & D. Not Effective \\
20 & $15 \%$ & $35 \%$ & $25 \%$ & $10 \%$ & $5 \%$ & $\mathrm{~B}$ & Effective \\
21 & $15 \%$ & $5 \%$ & $70 \%$ & $0 \%$ & $5 \%$ & $\mathrm{C}$ & D. Not Effective \\
22 & $20 \%$ & $10 \%$ & $25 \%$ & $30 \%$ & $5 \%$ & $\mathrm{D}$ & Effective \\
23 & $70 \%$ & $10 \%$ & $5 \%$ & $10 \%$ & $0 \%$ & $\mathrm{~A}$ & E. Not Effective \\
24 & $15 \%$ & $0 \%$ & $10 \%$ & $55 \%$ & $5 \%$ & $\mathrm{D}$ & B. Not Effective \\
25 & $10 \%$ & $60 \%$ & $15 \%$ & $10 \%$ & $0 \%$ & $\mathrm{~B}$ & E. Not Effective \\
\hline
\end{tabular}

Table 10. Classification of item items based on distinguishing features

\begin{tabular}{cccc}
\hline & Pre-Test & Post-Test & Gain Score \\
\hline Total & 1.212 & 1.712 & 11.5 \\
Average & 60.6 & 85.6 & 0.57 \\
Percentage of completeness & $20 \%$ & $90 \%$ & \\
\hline
\end{tabular}

Based on the information in Table 10, the average learning outcomes obtained through the pre-test are 60.6. Then, after getting treated using web-based mind mapping learning media, the average student learning outcomes have increased to 85.6. From the analysis of the pre-test and posttest results using the gain score value that is equal to 0.57 , which has moderate criteria. Thus it can be concluded that an increase in students' understanding and learning media can be declared effective for use by students in teaching and learning activities in class. The statistical tests were used to Strengthen the results of the gain score analysis. This test was conducted to determine the significance of the difference between student grades before and after treatment. The statistical test method to be used depends on the results of data normality. If the data normally distributed, then the $\mathrm{t}$-test is used. If the data not normally distributed, then the Wilcoxon test is performed.

The normality test carried out using the One-Sample Kolmogorov-Smirnov Test. Data analysis was performed to find out the pre-test and post-test results obtained by researchers who were normally distributed or not. If the Kolmogorov-Smirnov probability value $\alpha>0.05$, then the data is normally distributed, but if the Kolmogorov-Smirnov probability value $\alpha<0.05$, then the data is not normally distributed. A summary of this normality test can see in Table 11. 
Table 11. Classification of item items based on distinguishing features

\begin{tabular}{llcc}
\hline & One-Sample Kolmogorov-Smirnov Test & & \\
& & Pretest & Posttest \\
$N$ & & 20 & 20 \\
\hline Normal Parameters $^{a}$ & Mean & 60.60 & 85.60 \\
& Std. Deviation & 13.252 & 7.830 \\
Kolmogorov-Smirnov Z & & 1.199 & 0.762 \\
Asymp. Sig. (2-tailed) & & 0.113 & 0.607 \\
a. Test distribution is Normal. & & \\
\hline
\end{tabular}

This summary of normality test results informs that all data from the pre-test and post-test results normally distributed. Kolmogorov-Smirnov p-value for the pre-test is 0.113 , that more significant than 0.05 . For the post-test results, the Kolmogorov-Smirnov probability value is also higher than 0.05 , which is 0.607 . Thus the statistical test chosen is the t-test.

This t-test phase was carried out to see the significance of increasing students' understanding after using learning media by comparing pre-test and post-test scores. In this study to calculate the ttest using the statistics software. If the probability value obtained $\alpha>0.05$, it means that ineffective web-based mind mapping learning media use to improve students' understanding because there is no significant difference between the pre-test and post-test scores. If the probability value $\alpha<0.05$ indicates that the web-based mind mapping learning media is useful to use in increasing students' understanding because it is proven that there are real differences in student scores between before and after treatment.

Table 12. T-Test Result

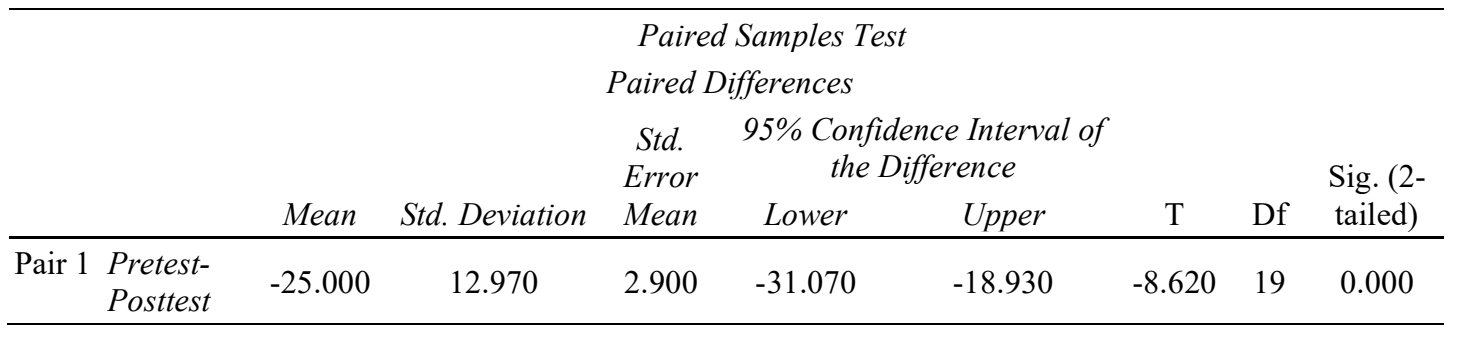

A summary of the results of t-test calculations can see in table 12. Following the t-test table results (paired sample test), it knows that results show that the web-based mind mapping learning media effectively improves the understanding of participants' learning students. The basis of this conclusion is the results of the t-test, which states that there are significant differences between student learning outcomes before and after using learning media. A probability value of 0,000 smaller than 0.05 states that there is a significant difference between student scores before using instructional media and after using.

Of course, these results cannot use as general generalizations. Trials that are only limited and only use one test group have many shortcomings. This test is only a preliminary test in product development to get an initial picture of successful development. Larger scale tests are still needed. Not only on a broader scale, but also differences in trial methods and learning conditions are required. Information from further trials is more accurate. However, as an initial step focusing on developing limited tests, this is also very important.

The mind mapping framework applied to the learning media developed proved successful in increasing student understanding. The results of the analysis of student need at the defined stage, which recommends several indicators to given special attention, which is then followed up by multiplying branching and practice questions, contribute to this result. Branching that is made interactive also plays a role in stimulating the active mental processes of each student. The material is provided to concisely so that it is easy to remember and can last longer in students' long term 
memory because there is a repetition process that is not relatively boring compared to conventional media.

Research Abi-El-Mona and Adb-El-Khalick (2006) found that the average student who used mind mapping learning media while teaching and learning activities gained $15 \%$ in terms of conceptual understanding. This result is supported by Buzan (2013), who also concluded that the media he used could increase students' understanding. Based on the process of developing and testing the media, it can conclude that this study does not conflict with some previous studies. Empirically these conclusions and research products can be used to enhance learning further. Of course, a more extensive trial still needed to find out the deficiencies that need to fix.

\section{CONCLUSION}

Based on the suitability of the results and discussions obtained by researchers, it can conclude that the web-based mind mapping learning media is useful for supporting teaching and learning activities in the classroom. Feasibility obtained from the web-based mind mapping learning media was analyzed based on the study results and validation of the material, media, and evaluation by experts and was declared eligible for use. Meanwhile, practicality obtained from the overall value of students' responses to the mind-based learning media web mapping gained $95.9 \%$ values, which has excellent criteria. This result shows that students are very interested in learning by using webbased mind mapping learning media.

This learning media's effectiveness is seen based on the learning outcomes of students through pre-test and post-test by using gain score analysis and t-test. Based on the results of the study of the gain score and t-test obtained that there was an increase in student learning outcomes. So it can be concluded that web-based mind mapping learning media is appropriate to be used to increase understanding of the material to support learning activities inside and outside the classroom. Because by using web-based mind mapping media, the active mental processes of each student become stimulated. The material provided so that it is easy to remember and able to last longer in long term memory because there is a repetition process that is relatively not boring compared to conventional media.

\section{REFERENCES}

Abi-El-Mona, I., \& Adb-El-Khalick, F. (2008). The influence of mind mapping on eighth graders' science achievement. School Science and mathematics, 108(7), 298-312. doi:https://doi.org/10.1111/j.1949-8594.2008.tb17843.x

Arikunto, S. (2007). Prosedur penelitian suatu pendekatan praktik. Jakarta: PT Rineka Cipta. doi:https://doi.org/10.1029/1998JC900010

Arikunto, S. (2012). Dasar-dasar evaluasi pendidikan (2nd ed.). Jakarta: Bumi Aksara.

Arsyad, A. (2011). Media pembelajaran. Jakarta: Rajawali Pers.

Aulia, S. (2014). Penerapan model mind mapping dan inside-outside circle untuk meningkatkan aktivitas dan hasil belajar PKN siswa kelas V SDN Pelambuhan 7 Banjarmasin (Unpublished bachelor thesis). Universitas Negeri Malang, Malang.

Bergdahl, N., Nouri, J., Fors, U., \& Knutsson, O. (2020). Engagement, disengagement and performance when learning with technologies in upper secondary school. Computers \& Education, 149, 103783. doi:https://doi.org/10.1016/j.compedu.2019.103783

Biktimirov, E. N., \& Nilson, L. B. (2006). Show them the money: Using mind mapping in the introductory finance course. Journal of Financial Education, 32, 72-86. doi:https://doi.org/10.2307/41948535

Buran, A., \& Filyukov, A. (2015). Mind mapping technique in language learning. Procedia-Social and Behavioral Sciences, 206, 215-218. doi:https://doi.org/10.1016/j.sbspro.2015.10.010 
Buzan, T. (2013). Buku pintar mind map. Jakarta: PT Gramedia Pustaka Utama.

Cheng, B., Wang, M., \& Mercer, N. (2014). Effects of role assignment in concept mapping mediated small group learning. Internet and Higher Education, 23, 27-38. doi:https://doi.org/10.1016/j.iheduc.2014.06.001

Chuang, Y.-T. (2014). Increasing learning motivation and student engagement through the technology-supported learning environment. Creative Education, 5(23), 1969-1978. doi:https://doi.org/10.4236/ce.2014.523221

Clay, C. (2011). Exploring the use of mobile technologies for the acquisition of clinical skills. Nurse Education Today, 31(6), 582-586. doi:https://doi.org/doi.10.1016/j.nedt.2010.10.011

D'Antoni, A. V. (2009). Relationship between the mind map learning strategy and critical thinking in medical students (Unpublised doctoral dissertation). Seton Hall University, New Jersey.

Daiute, C. (2013). Educational uses of the digital world for human development. LEARNing Landscapes, 6(2), 63-83. doi:https://doi.org/10.36510/learnland.v6i2.605

Darusman, R. (2014). Penerapan metode mind mapping (peta pikiran) untuk meningkatkan kemampuan berpikir kreatif matematik siswa SMP. Infinity Journal, 3(2), 164-173. doi:https://doi.org/10.22460/infinity.v3i2.61

Daryanto, D. (2010). Evaluasi pendidikan. Jakarta: Rineka Cipta.

Evrekli, E., Inel, D., \& Balim, A. G. (2011). A research on the effects of using concept cartoons and mind maps in Science Education. Necatibey Eğitim Fakültesi Elektronik Fen ve Matematik Eğitimi Dergisi, 5(2), 58-85.

Fu, Q. K., Lin, C. J., Hwang, G. J., \& Zhang, L. (2019). Impacts of a mind mapping-based contextual gaming approach on EFL students' writing performance, learning perceptions and generative uses in an English course. Computers \& Education, 137, 59-77. doi:https://doi.org/10.1016/j.compedu.2019.04.005

Ghozali, I. (2009). Aplikasi analisis multivariate dengan program SPSS. Semarang: BP UNDIP.

Harmi, H. (2010). Teori belajar dan pembelajaran. Curup: LP2 STAIN.

Kaplan, R. M., \& Saccuzzo, D. P. (2001). Psychological testing: Principles, applications, and issues (5th ed.). Thomson Learning.

Karras, D. J. (1997). Statistical methodology: II. Reliability and validity assessment in study design, part B. Academic Emergency Medicine, 4(2), 144-147. doi:https://doi.org/10.1111/j.15532712.1997.tb03723.x

Kiong, T. T., Yunos, J. B. M., Mohammad, B. B., Othman, W. B., Heong, Y. M., \& Mohamad, M. M. B. (2012). The development and evaluation of the qualities of Buzan mind mapping module. Procedia-Social and Behavioral Sciences, 59, 188-196. doi:https://doi.org/10.1016/j.sbspro.2012.09.264

Otaduy, I., \& Diaz, O. (2017). User acceptance testing for Agile-developed web-based applications: Empowering customers through wikis and mind maps. Journal of Systems and Software, 133, 212-229. doi:https://doi.org/10.1016/j.jss.2017.01.002

Prabowo, M. (2010). Pembelajaran di sekolah: Harapan dan kenyataan. Majalah Ilmiah Pembelajaran.

Prayudi, P. (2008). Pengaruh penggunaan strategi pembelajaran mind mapping terhadap prestasi belajar. Jakarta.

Rahayu, A. H., Santosa, S., \& Endarto, D. (2015). Upaya meningkatkan motivasi dan hasil belajar geografi melalui penerapan media audio visual dengan metode mind map (Penelitian 
118 - Harmoni Sosial: Jurnal Pendidikan IPS

tindakan kelas pada siswa kelas X-6 SMA Negeri I Kroya, Kec. Kroya, Kab. Cilacap, tahun ajaran 2012/2013). GeoEco, 1(1), 10-17.

Richey, R. (2008). Reflection on the 2008 AECT definitions of the field. TechTrends.

Riduwan, R. (2016). Skala pengukuran variabel-variabel penelitian. Bandung: Alfabeta.

Rusman. R. (2013). Model-model pembelajaran. Jakarta: Rajawali Pers.

Sadiman, A.S., Rahardjo, R., Haryono, A., \& Harjito, H. (2007). Media pendidikan. Jakarta: PT Raja Grafindo.

Shoimin, A. (2014). 68 Model pembelajaran inovatif dalam kurikulum 2013. Yogyakarta: Ar-Ruzz Media.

Sim, M.-A. (2012). Mind Mapping and Brainstorming As Methods of Teaching Business Concepts in English As a Foreign Language. Academica Science Journal Psychologica Series No, 1(1), 2012.

Sim, M. A., \& Pop, A. M. (2012). Mind mapping and brainstorming as methods of teaching business concepts in English as a foreign language. Academica Science Journal, Psychologica Series, 1,75 .

Sinclair, P.M., Kable, A., Levett-Jones, T., \& Booth, D. (2016). The effectiveness of internet-based e-learning on clinician behavior and patient outcomes: A systematic review. International Journal of Nursing Studies, 57, 70-81. doi:https://doi.org/10.1016/j.ijnurstu.2016.01.011

Sudijono, A. (2009). Pengantar evaluasi pendidikan. Jakarta: Rajawali Pers.

Sugiyono, S. (2016). Metodelogi penelitian kuantitatif, kualitatif, dan R\&D. Bandung: Alfabeta.

Sukardi, S. (2011). Evaluasi pendidikan: Prinsip dan operasionalnya. Jakarta Timur: PT Bumi Aksara.

Surjono, H. D. (2013). Membangun course e-learning berbasis moodle. UNY Press.

Surjono, H. D. (2010). Pemanfaatan Teknologi Informasi dan Komunikasi dalam Peningkatan Kualitas Pembelajaran. Paper presented at Seminar MGMP Terpadu SMP/MTs Kota Magelang, Magelang, Indonesia.

Thoha, M. C. (2001). Teknik evaluasi pendidikan. Jakarta: PT RajaGrafindo Persada.

Trianto, T. (2014). Model pembelajaran terpadu (Konsep, strategi, dan implementasinya dalam Kurikulum Tingkat Satuan Pendidikan). Jakarta: PT Bumi Aksara.

Yu, J., Zhang, W., Yang, Z., Qin, Z., \& Hu, Y. (2020). Cross-modal learning with prior visual relation $\begin{array}{llll}\text { knowledge. Knowledge-Based } & \text { Systems, } & 203, & 106150 .\end{array}$ doi:https://doi.org/10.1016/j.knosys.2020.106150 